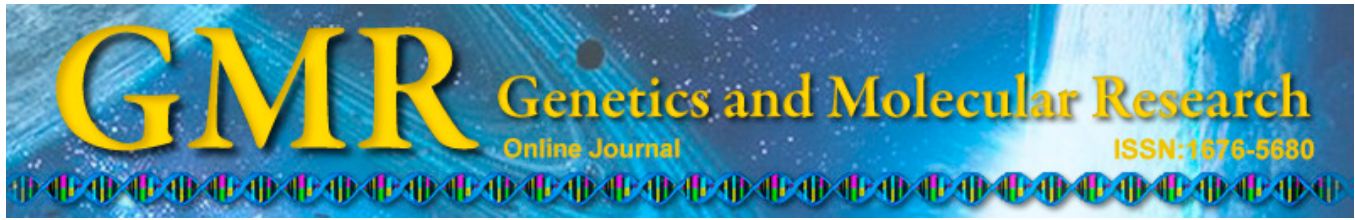

\title{
Cross-species transferability of microsatellite markers in the genus Lippia
}

C.P. Santos ${ }^{1}$, D.S. Rocha ${ }^{2}$, M.M. Bajay ${ }^{3}$, F.R.C. Santos ${ }^{2}$, J.B. Campos ${ }^{3}$, J.B. Pinheiro ${ }^{3}$, M.I. Zucchi ${ }^{2}$, R. Silva-Mann ${ }^{1}$, M.F. Arrigoni-Blank ${ }^{1}$ and A.F. Blank ${ }^{1}$

1Programa de Pós-Graduação em Biotecnologia de Recursos Naturais, Universidade Federal de Sergipe, São Cristóvão, SE, Brasil

${ }^{2}$ Laboratório de Biologia Molecular,

Agência Paulista de Tecnologia dos Agronegócios, Polo Centro Sul, Piracicaba, SP, Brasil

${ }^{3}$ Laboratório de Diversidade Genética e Melhoramento, Departamento de Genética e Melhoramento de Plantas, Escola Superior de Agricultura "Luiz de Queiroz", Universidade de São Paulo, Piracicaba, SP, Brasil

Corresponding author: A.F. Blank

E-mail: afblank@ufs.br

Genet. Mol. Res. 13 (4): 9846-9850 (2014)

Received February 3, 2014

Accepted May 3, 2014

Published November 27, 2014

DOI http://dx.doi.org/10.4238/2014.November.27.11

ABSTRACT. The cross-species transferability of 20 microsatellite
markers was tested in the genus Lippia. Eleven markers were
polymorphic after screening 19 accessions of Lippia sidoides and
Lippia gracilis maintained in the Active Germplasm Bank (AGB)
from Universidade Federal de Sergipe. Additionally, 40 accessions
of Lippia spp were collected in Sergipe to increase the germplasm
bank. A total of 23,22 , and 36 alleles were identified, with an
average of $2.3,2.2$, and 3.27 alleles per locus, respectively, for
each group. The markers that were used were efficient tools to 
access genetic diversity in the germplasm bank and will be useful for further research aiming at the conservation and management of these important aromatic species.

Key words: Genetic diversity; Lippia sidoides; Lippia gracilis; Lippia alba; Microsatellite markers; Transferability

\section{INTRODUCTION}

The genus Lippia consist of about 200 species of herbs, shrubs, and small trees of vegetative propagation, which are often aromatic (Terblanché and Kornelius, 1996). In this genus, the aromatic species Lippia sidoides and Lippia gracilis, which are native of northeastern Brazilian, might be highlighted because of the strong bactericidal, fungicidal, and acaricidal activity that is conferred by their essential oil because of the predominance of the monoterpenes thymol and carvacrol (Albuquerque et al., 2006; Botelho et al., 2007; Cruz et al., 2013).

The Universidade Federal de Sergipe (UFS) has a germplasm collection of $L$. sidoides and $L$. gracilis. However, there is no information about its genetic diversity for the management of these germplasms and future breeding programs. In this sense, microsatellite markers, or simple sequence repeats (SSRs), have been an efficient alternative because of their codominance, polymorphic and multi-allelic nature, abundance, and wide coverage of the genome (Buso et al., 2003). Because the development of SSR primers for each locus is associated with high costs and labor intensity, these markers are mainly available for some economically important crops. However, closely related species have conserved sequences that flank SSRs, which makes it possible to share primers among species (Kuleung et al., 2004). In this study, we determined the transferability of a set of markers that were developed and characterized for Lippia alba (Mill) N. E. Br. to characterize the genetic diversity of the Active Germplasm Bank (AGB) of L. sidoides and L. gracilis.

\section{MATERIAL AND METHODS}

Young leaves of 12 accessions of L. sidoides and 7 accessions of L. gracilis that were maintained in the AGB of UFS were collected for DNA extraction. Because of the small number of genotypes, a set of 40 accessions of Lippia spp was collected for the introduction of new divergent genotypes to expand the AGB. The plant material was immediately stored in liquid nitrogen and lyophilized. After lyophilization, the plant material was ground and stored at $-20^{\circ} \mathrm{C}$. DNA extraction was performed according to the cetyltrimethylammonium bromide protocol described by Doyle and Doyle (1990). The quantity and quality of the obtained DNA were analyzed on $1 \%$ agarose gels that were stained with SYBR safe using different concentrations of phage lambda DNA.

A set of 11 markers that were characterized by Santos et al. (2012) and 9 microsatellite markers characterized in L. alba (Rocha et al., 2014) were screened for their transferability to 59 accessions of $L$. sidoides and L. gracilis. For all loci, the 5 '-end of the forward primer was attached to an M13 tag (5'-CACGACGTTGTAAAACGAC-3'). The polymerase chain reac- 
tions (PCRs) were performed in a $20-\mu \mathrm{L}$ volume containing $2 \mu \mathrm{L}$ genomic DNA (10 ng), 11.9 $\mu \mathrm{L}$ ultrapure water, $2.0 \mu \mathrm{L}$ buffer Taq DNA polymerase [ $75 \mathrm{mM}$ Tris- $\mathrm{HCl}, 20 \mathrm{mM}\left(\mathrm{NH}_{4}\right)_{2} \mathrm{SO}_{4}$, $\mathrm{pH} 8.8,0.01 \%$ (v/v) Tween 20], $2.0 \mu \mathrm{L} 25 \mathrm{mM} \mathrm{MgCl}_{2}, 0.2 \mu \mathrm{L} 2.5 \mathrm{U} / \mu \mathrm{L}$ Taq DNA polymerase, $1.0 \mu \mathrm{L} 2.5 \mathrm{mM}$ dNTPs, $0.35 \mu \mathrm{L} 10 \mu \mathrm{M}$ of each primer (forward + reverse), and $0.2 \mu \mathrm{L} 10 \mu \mathrm{M}$ labeled tag with the fluorophore IRDye700 or IRDye800 (LI-COR Biosciences, Lincoln, NE, USA). The PCR amplifications were performed with a touchdown program under the following conditions: an initial cycle at $94^{\circ} \mathrm{C}$ for $5 \mathrm{~min} ; 10$ cycles touchdown at $94^{\circ} \mathrm{C}$ for $40 \mathrm{~s}$ for denaturation, annealing temperature of each primer for $40 \mathrm{~s}\left(-1^{\circ} \mathrm{C}\right)$, and $72^{\circ} \mathrm{C}$ for $1 \mathrm{~min}$ for fragment extension; 30 cycles at $94^{\circ} \mathrm{C}$ for $40 \mathrm{~s}, 40^{\circ} \mathrm{C}$ for $40 \mathrm{~s}$, and $72^{\circ} \mathrm{C}$ for $1 \mathrm{~min}$; and a final extension cycle at $72^{\circ} \mathrm{C}$ for $10 \mathrm{~min}$.

The products were initially verified on $2 \%$ agarose gels and then electrophoresed on an automated DNA sequencer LI-COR Model 4300 (LI-COR Biosciences) equipped with 2 infrared lasers with the ability to simultaneously read 2 wavelengths $(700-800 \mathrm{~nm})$, using the standard fragments (50-350 bp) labeled with fluorescence IRDye700 and IRDye800 (LI-COR Biosciences). The exact sizes of fragments were determined using the SAGA ${ }^{\mathrm{MX}}$ software version 3.3 (LICOR Biosciences). The number of alleles, observed heterozygosity, and expected heterozygosity were estimated using the MStools software (Park, 2001). The deviation from Hardy-Weinberg equilibrium (HWE) and linkage disequilibrium were verified by Genepop (Rousset, 2008).

\section{RESULTS AND DISCUSSION}

Of 20 SSR loci, $12(60 \%)$ were successfully transferred. Ten loci were moderately polymorphic in the AGB genotypes, and 11 loci were polymorphic in the collected Lippia accessions. A total of 23, 22, and 36 alleles, with an average of 2.30, 2.20, and 3.27 alleles per locus were identified for $L$. sidoides accessions in the AGB, L. gracilis accessions in the AGB, and Lippia spp accessions, respectively (Table 1). The expected heterozygosity ranged from 0.745 to $0.312,0.626$ to 0.143 , and 0.755 to 0.141 , while the observed heterozygosity ranged from 0.750 to $0.364,0.857$ to 0.143 , and 0.917 to 0.103 , for L. sidoides, L. gracilis, and Lippia spp accessions, respectively.

Six loci (LA08, LA09, LAD03, LAG05, LAB05, and LA02) departed significantly from HWE after Bonferroni's correction $(\mathrm{P}<0.05)$. However, accessions maintained in germplasm banks are not expected to be in HWE because they are collected from different populations and they do not mate (Bajay et al., 2009; Sandes et al., 2013). Loci in HWE are expected only in randomly mating populations (panmictic) after at least 1 generation of open pollination (Weir, 1996). The linkage disequilibrium was tested by adjusting the $\mathrm{P}$ value for the $5 \%$ nominal level, and no disequilibrium was detected among all loci.

The number of alleles and heterozygosity values confirm that the germplasm bank of L. sidoides and L. gracilis possesses considerable genetic variability, reinforcing the importance of conserving all genotypes. Some accessions of the collected Lippia spp were highly divergent, showing their importance and complementing the AGB. The described primers represent a useful tool for population genetics studies in Lippia. They can be used to verify the variability in other germplasm banks of Lippia spp, allowing the development of strategies for the conservation, management, and breeding programs of these important, endemic, medicinal, and aromatic species. 


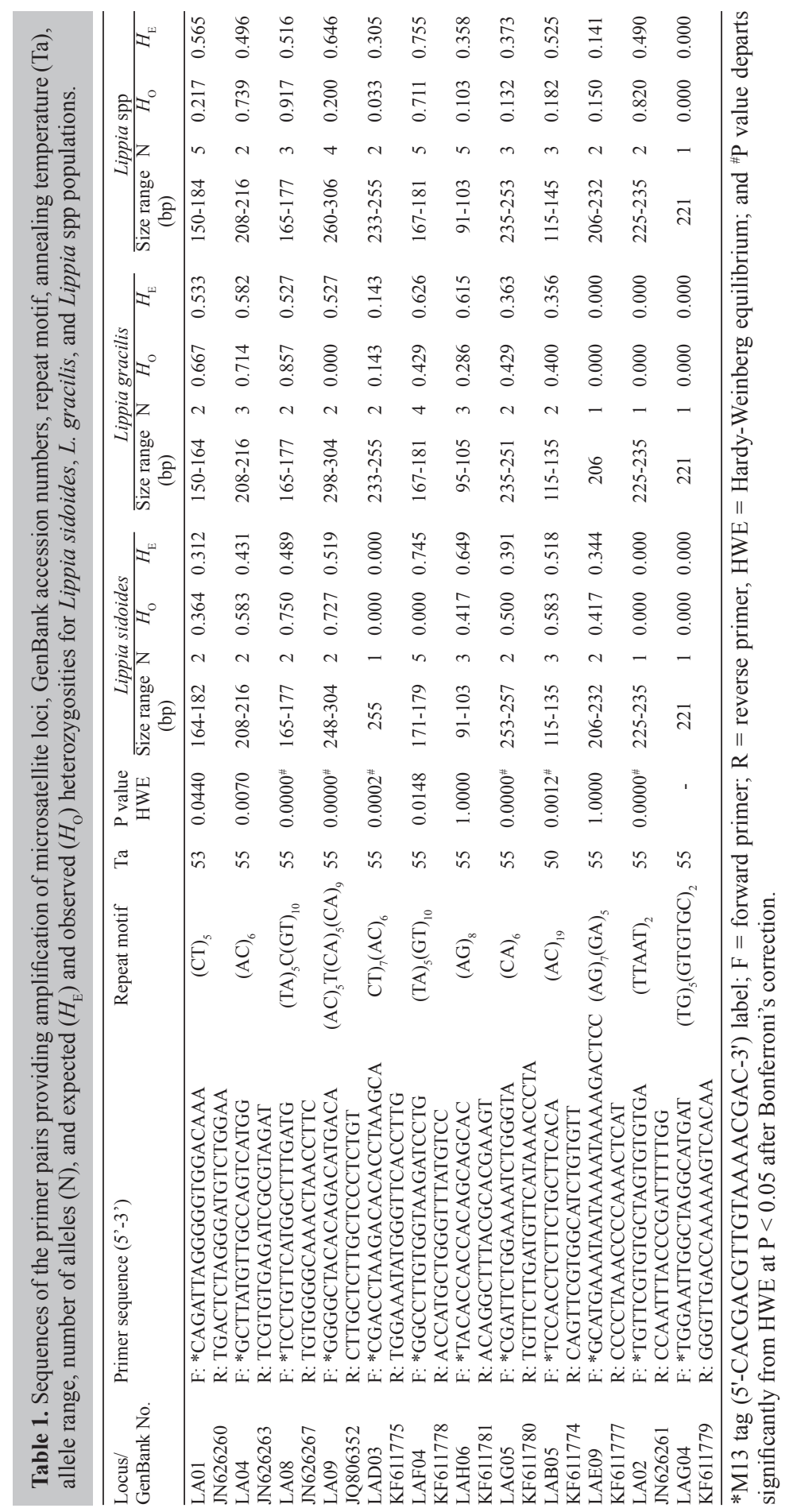




\section{ACKNOWLEDGMENTS}

The authors wish to thank the Fundação de Apoio à Pesquisa e à Inovação Tecnológica do Estado de Sergipe, Conselho Nacional de Desenvolvimento Científico e Tecnológico, and Coordenação de Aperfeiçoamento de Pessoal de Nível Superior for their financial support of this study.

\section{REFERENCES}

Albuquerque CC, Camara TR, Mariano RLR, Willadino L, et al. (2006). Antimicrobial action of the essential oil of Lippia gracilis Schauer. Braz. Arch. Biol. Technol. 49: 527-535.

Bajay MM, Pinheiro JB, Batista CEA, Nobrega MBM, et al. (2009). Development and characterization of microsatellite markers for castor (Ricinus communis L.), an important oleaginous species for biodiesel production. Conserv. Genet. Resour. 1: 237-239.

Botelho MA, Nogueira NA, Bastos GM, Fonseca SG, et al. (2007). Antimicrobial activity of the essential oil from Lippia sidoides, carvacrol and thymol against oral pathogens. Braz. J. Med. Biol. Res. 40: 349-356.

Buso GSC, Ciampi AY, Moretzsohn MC, Amaral ZPS, et al. (2003). Marcadores microssatélites em espécies vegetais. Biotecnol. Cienc. Desenvolv. 30: 46-50.

Cruz EMO, Costa-Junior LM, Pinto JAO, Santos DA, et al. (2013). Acaricidal activity of Lippia gracilis essential oil and its major constituents on the tick Rhipicephalus (Boophilus) microplus. Vet. Parasitol. 195: 198-202.

Doyle JJ and Doyle JL (1990). Isolation of plant DNA from fresh tissue. Focus 12: 13-15.

Kuleung C, Baenziger PS and Dweikat I (2004). Transferability of SSR markers among wheat, rye, and triticale. Theor Appl. Genet. 108: 1147-1150.

Park S (2001). MStools V.3 (Excel Spreadsheet Toolkit for Data Conversion), Smurfit Institute of Genetics Trinity College, Dublin.

Rocha DS, Santos CP, Bajay MM and Campos JB (2014). Development of a novel set of microsatellite markers for Lippia alba (Verbenaceae). Genet. Mol. Res. (in press).

Rousset F (2008). Genepop'007: a complete re-implementation of the Genepop software for Windows and Linux. Mol. Ecol. Resour. 8: 103-106.

Sandes SS, Pinheiro JB, Zucchi MI, Monteiro M, et al. (2013). Development and characterization of microsatellite primers in Pogostemon cablin (Lamiaceae). Genet. Mol. Res. 12: 2837-2840.

Santos FR, Lima PF, Priolli RH, Siqueira WJ, et al. (2012). Isolation and characteristics of eight novel polymorphic microsatellite loci in Lippia alba (Verbenaceae). Am. J. Bot. 99: e301-e303.

Terblanché FC and Kornelius G (1996). Essential oil constituents of the genus Lippia (Verbenaceae) - a literature review. J. Essent. Oil Res. 8: 471-485.

Weir BS (1996). Genetics Data Analysis II: Methods for Discrete Population Genetic Data. Sinauer Associates, Sunderland. 